\title{
Economic benefits of a routine second dose of combined measles, mumps and rubella vaccine in Canada
}

Marc Rivière MD, Roma Tretiak MHA, Carey Levinton BSc, Catherine Fitzsimon BSc, Caroline Leclerc BScN

M Rivière, R Tretiak, C Levinton, C Fitzsimon, C Leclerc. Economic benefits of a routine second dose of combined measles, mumps and rubella vaccine in Canada. Can J Infect Dis 1997:8(5):257-264.

OBJECTIVE: To evaluate the potential economic benefits of a program for a second routine dose of combined measles, mumps and rubella (MMR) vaccine, administered to children in Canada.

DESIGN: Both published and unpublished data from the United States and Canada were incorporated into a linear model. This information was supplemented with opinions on probability and resource use from interviews with a Canadian panel of physicians and practitioners. The province of Quebec was used as a model for resource use and costs. MATERIAL AND METHODS: Data were based on a vaccination program for Canadian children at 18 months, with an estimated annual birth cohort of 400,000. Further data were also collected for the lifetime costs of complications arising from these diseases or from vaccination, for both patients and family caregivers.

OUTCOME MEASURES: Outcomes were reviewed from the perspectives of a provincial ministry of health (direct medical costs) and of society (all direct and indirect medical and nonmedical costs).

RESULTS: It was estimated that a second dose of MMR vaccine administered at 18 months of age would prevent 9200 cases of measles, 6120 cases of mumps and 1960 cases of rubella, producing a savings of $\$ 6.34$ for every dollar spent from the ministry of health perspective, and $\$ 3.25$ from the societal perspective.

CONCLUSIONS: A routine second dose immunization with MMR vaccine would result in considerable cost savings in Canada.

Key Words: Benefit-cost, Economics, Measles, Mumps, Rubella, Second dose vaccine

\section{Bénéfices économiques d'une seconde dose de routine du vaccin combiné de la rougeole, des oreillons et la rubéole au Canada}

OBJECTIF : Lóbjectif de cette étude coût-bénéfice était d'évaluer les bénéfices économiques potentiels dún programme d'ádministration dúne deuxième dose de routine du vaccin combiné de la rougeole, des oreillons et de la rubéole (ROR), pour les enfants du Canada.

DESIGN : Les données publiées et non publiées des États-Unis et du Canada étaient incorporées à un modèle linéaire. Cette information était complétée par des opinions sur la probabilité et l'utilisation de ressource au cours déntrevues auprès dún comité de praticiens et médecins canadiens. La province de Québec a été utilisée comme modèle pour l'utilisation de ressource et de coûts.

PARTICIPANTS : Les données recueillies étaient basées sur un programmme de vaccination pour les enfants canadiens

voir page suivante 
âgés de 18 mois, avec use cohorte de naissance annuelle estimée à 400 000. Dáutres données étaient aussi recueillies pour les coûts, à vie, de complicationsprovenant de ces maladies, ou de la vaccination, tant pour les patients que pour les personnes soignantes familiales.

MESURES DE RÉSULTATS : Les résultats sont revus selon les pespectives dún ministère provincial de la santé (coûts médicaux directs) et de la société (tous coûts médicaux et non-médicaux et no médicaux directs et indirects).

MESURES DE RÉSULTATS : Les résultats sont revus selon les perspectives dún ministère provincial de la santé (coûts médicaux directs) et de la société (tous les coûts médicaux et non-médicaux directs et indirects).

RÉSULTATS : Il était estimé quúne deuxième dose du vaccin combiné rougeole, oreillons et rubéole, administrée à des enfants âgés de 18 mois, préviendrait 9200 cas de rougeole, 6120 cas dóreillons et 1960 cas de rubéole, produisant use épargne de $6.34 \$$ pour chaque dollar dépensé selon la perspective du minist1ere de la snaté et $3.25 \$$ selon lángle sociétal.

CONCLUSIONS: Une immunisation par l'administration, en routine, dúne seconde dose du vaccin rougeole, oreillons et rubéole, résulterait en des épargnes considérables au Canada.

$\mathrm{M}$ easles, mumps and rubella (MMR) vaccine (Measles, Mumps \& Rubella Virus Vaccine Live Attentuated, Merck Sharp and Dome) is used in Canada for routine single dose immunization against measles (rubeola), mumps and rubella (German measles). The vaccine has made an undisputed contribution to the reduction of the morbidity, mortality and burden of illness associated with these conditions (1). The ensuing economic savings have been consistently demonstrated $(2,3)$.

Widespread use of the vaccine has decreased the incidence of MMR by at least $90 \%$ (4). However, despite high coverage rates in Canada, certain individuals remain susceptible to the diseases. Susceptibility remains high for three reasons: in some cases the first dose does not take effect; some children experience a waning immunity to the diseases; and a small percentage of children ( $3 \%$ to $5 \%$ ) do not receive the initial vaccination. Carried out at various intervals, serosurveys of children who had received a routine first dose of MMR vaccine following their first birthday have shown that $2 \%$ to $12 \%$ of those tested lacked antibodies to measles. In addition, 3\% to $19 \%$ of the children lacked antibodies to mumps and $1 \%$ to $6 \%$ were lacking antibodies to rubella (5). However, an American study has shown that most children who test negative for measles antibody after a first vaccination respond to a revaccination and retain protective antibody levels (6).

Measles is the most contagious of these three vaccinepreventable diseases; experience from the past decade indicates that outbreaks can still occur in populations with virtually $100 \%$ vaccination coverage (5). From 1989 to 1991 there was a major resurgence of measles in the United States (7). Mumps and rubella are relatively mild, self-limited diseases, but they also increased in incidence in the late 1980s (8).

In 1989, a province-wide outbreak of measles in Quebec resulted in the deaths of several children, put another 656 in hospital and left close to 10,000 others infected with the virus (9). At the same time (1988 to 1989) in the area of Rivière du Loup, Québec, an outbreak of 440 cases of mumps was reported (10). A Quebec study also revealed that congenital rubella syndrome continues to be a problem (personal communication).

Overall, Canada experienced a 2.5-fold increase in measles in 1994 and an additional sharp increase in 1995. The total number of cases in 1995 (2100 up to October 31) was about 10 times the total in the United States for the same period. Suffi- cient numbers of unprotected children exist in every province to support predictions of outbreaks in Canada in excess of 20,000 cases (5).

Several countries have implemented a policy of administering a second dose of MMR vaccine to prevent such resurgence. Since 1982, after receiving a first vaccination with MMR vaccine between the ages of 14 and 18 months, all children in Finland receive a second injection at six years of age. The result has been the successful elimination of indigenous MMR in that country (11). The United States, New Zealand and the Netherlands also use a two-dose MMR strategy (12).

At present, children in Canada are given one routine dose of MMR vaccine at 12 months; however, some provinces and territories have now begun programs for a routine second dose at either 18 months or between four and six years of age. The National Advisory Committee on Immunization (NACI) recently recommended that a second dose of MMR vaccine be routinely offered in Canada to increase protection (5). While the cost of monovalent measles vaccine is less, MMR vaccine is preferred because a proportion of children will also derive protection against rubella and mumps. The NACI foresees meeting three goals with this strategy: the elimination of measles in Canada by the year 2005; minimization of the serious sequelae of mumps; and elimination of indigenous rubella infection during pregnancy by the year 2000 (13). It would be most practical to link the second dose of MMR vaccine with other routine vaccinations (eg, those next scheduled at 18 months, or school-entry vaccinations between ages four and six). The provinces of Quebec, Newfoundland and British Columbia, and the Yukon and the Northwest Territories are implementing second dose programs for 18-month-old children. At the time of submission, Nova Scotia, Ontario, Prince Edward Island, Manitoba and Alberta had also begun routine second MMR vaccination for preschool children (14-17).

Data on the economic consequences of MMR in Canada and the potential economic advantages of a second dose of MMR vaccine have not been explored. Therefore, the objectives of this study were to outline the cost of MMR in Canada and to evaluate the economic efficiency of a routine second dose of MMR vaccine, administered at 18 months of age. Analyses were performed from the perspective of a provincial ministry of health $(\mathrm{MOH})$; all costs experienced outside the $\mathrm{MOH}$, as well as those within, were also evaluated (society perspective). 
TABLE 1

Sources of direct and indirect costs for treatment of measles, mumps and rubella from the perspective of a ministry of health and society

\begin{tabular}{l} 
Ministry of health \\
Vaccine \\
Physician consultations \\
Hospitalization (due to complications) \\
Institutionalization (eg, long term care) \\
Investigations \\
Allied health workers (eg, physiotherapist) \\
Medication \\
Medical equipment \\
Rehabilitation \\
Society \\
All costs in ministry of health analysis \\
Special schools (eg, for the deaf, blind) \\
Indirect costs (days missed from work) \\
\hline
\end{tabular}

\section{MATERIALS AND METHODS}

Design: In this cost of consequences study, the consequences of a second dose of MMR vaccine were estimated in terms of the number of cases of MMR and their complications avoided by use of the vaccine. The costs saved by averting these diseases were calculated and compared with the cost of implementing the second dose program. The relationship was expressed as an incremental ratio, and a benefit-cost ratio was determined. Prevalence, incidence and outbreak-control risk were defined as the epidemiological variables; published and unpublished American and Canadian data were used to identify and quantify these parameters. In the absence of relevant data, information was adopted from the Centre de Santé Publique de la Region de Québec (CSPRQ) location, a provincial public health agency.

Study end-points: The primary clinical end-point of the study was the total number of cases that would be avoided (including complications) by a second dose of MMR vaccine at 18 months of age. The economic end-points evaluated were the direct costs for in-patient care (length of stay in hospital or institutionalization), out-patient care (consultations, laboratory and diagnostic tests, procedures, and drugs) and the costs of controlling a disease outbreak. The indirect cost of days missed from work by the patients and their caregivers over the patient's lifetime and extra nonmedical costs for special schools or institutionalization (due to years of work lost by the patient) were also evaluated as a secondary end-point. Items included for each perspective ( $\mathrm{MOH}$ or society) are shown in Table 1.

Model design: It is not logistically possible to follow large cohorts of children in Canada for a long period of time. This factor and a lack of published data led to the development of a linear decision-tree model that simulated a long term follow-up of large cohorts for the entire population of newborn children in Canada. Clinical data were used to establish the benefits of a second injection, and economic data were used to assess utilization of health care resources and associated costs.

The model projected outcomes of a routine second dose of
TABLE 2

Probabilities and sources

\begin{tabular}{|c|c|c|}
\hline Disease & Probability & Source \\
\hline Measles & 0.025 & 20 \\
\hline \multicolumn{3}{|l|}{ No complication } \\
\hline $\begin{array}{l}\text { Outbreak } \\
\text { probability }\end{array}$ & $\begin{array}{l}0.10 \text { per year } \\
\text { (every } 10 \text { years) }\end{array}$ & 21 \\
\hline Death (measles) & 0.001 & 4 \\
\hline Otitis & 0.03 & 4 \\
\hline Pneumonia & 0.045 & 4 \\
\hline Encephalitis & 0.001 & 4 \\
\hline Mumps & 0.017 & 20 \\
\hline \multicolumn{3}{|l|}{ No complication } \\
\hline $\begin{array}{l}\text { Outbreak } \\
\text { probability }\end{array}$ & $\begin{array}{c}\text { 0.05/year } \\
\text { (every } 20 \text { years) }\end{array}$ & $\begin{array}{c}\text { Personal } \\
\text { communication }^{\dagger}\end{array}$ \\
\hline Death (mumps) & 0 & Data on file* \\
\hline Encephalitis & 0.0015 & 3 \\
\hline Orchitis & 0.05 & Data on file* \\
\hline Meningitis & 0.001 & 3 \\
\hline Deafness & 0.000005 & 3 \\
\hline Rubella & 0.005 & 20 \\
\hline \multicolumn{3}{|l|}{ No complication } \\
\hline $\begin{array}{l}\text { Outbreak } \\
\text { probability }\end{array}$ & 0 & 19 \\
\hline Death (rubella) & 0 & Data on file* \\
\hline Abortion & 0 & 19 \\
\hline $\begin{array}{l}\text { Congenital rubella } \\
\text { syndrome }\end{array}$ & $\begin{array}{c}0.000045 \\
(18 \text { cases } / 400,000)\end{array}$ & $\begin{array}{c}\text { Personal } \\
\text { communication }^{\dagger}\end{array}$ \\
\hline $\begin{array}{l}\text { Cardiac } \\
\text { malformations }\end{array}$ & 0.46 & 22 \\
\hline Deafness & 0.87 & 22 \\
\hline Eye problems & 0.34 & 22 \\
\hline Mental retardation & 0.39 & 22 \\
\hline Thrombocytopenia & 0.00033 & 3 \\
\hline Arthritis & 0.19 & Data on file*, 20 \\
\hline
\end{tabular}

\section{Vaccination}

Vaccine failure

$\begin{array}{lll}\text { Mumps } & 0.10 & 20 \\ \text { Measles } & 0.08 & 20 \\ \text { Rubella } & 0.02 & 20 \\ \text { Fever } & 0.1 & 23 \\ \text { Rash } & 0.1 & 23\end{array}$

Anaphylaxis $0.00001 \quad$ Data on file*

*Merck Frosst Canada Inc. ${ }^{\dagger}$ Gaston de Serres, Centre de santé publique due Québec, Québec, Québec

MMR vaccine administered at 18 months of age over a followup period of 20 years. The number of births in Canada has been estimated at 400,000 per year and was presumed to be constant over time (ie, a steadystate model) (18). It was also assumed that children would be vaccinated at both 12 and 18 months of age. From the initial point (birth), there were two treatment arms, one representing a routine first dose only and the other a routine first and second dose of MMR vaccine.

Four possible outcomes were projected for each treatment arm - no complications, short term complications, long term complications and death - for each disease. Probabilities of 
TABLE 3

Anticipated cases of disease in the absence of a routine second dose of measles, mumps and rubella vaccine (per 400,000 birth cohort)

\begin{tabular}{lc} 
Disease & Cases avoided \\
\hline Measles & \\
Uncomplicated & 8492 \\
With complications & \\
$\quad$ Otitis & 276 \\
Pneumonia & 414 \\
Encephalitis & 9 \\
Total cases with complications & 699 \\
Mumps & \\
Uncomplicated & 5799 \\
With complications & 9 \\
Encephalitis & 306 \\
Orchitis & 6 \\
Meningitis & $0 *$ \\
Deafness & 321 \\
Total cases with complications & 1687 \\
Rubella & \\
Uncomplicated & \\
With complications & \\
Thrombocytopenia & \\
Arthritis & \\
Congenital rubella syndrome & \\
Total cases with complications & \\
& \\
\hline
\end{tabular}

*0.03 cases

contracting each disease and of complications resulting from the diseases (with either one or two doses of the vaccine), complications arising from the vaccine itself and probabilities for potential outbreaks for each disease were established from published and unpublished data and with information obtained from the CSPRQ (19). These probabilities and their sources are presented in Table 2 .

Complications arising from measles included respiratory tract infections, otitis and encephalitis; complications arising from mumps included meningitis, encephalitis, orchitis and hearing impairment; and complications arising from rubella included congenital rubella syndrome (CRS), arthritis and thrombocytopenia.

Short term consequences were identified as acute events directly related to the ongoing infection (with or without complications), as well as acute events related to the vaccine itself. Sequelae and complications from the infection were identified as long term consequences for all segments of the population susceptible to the disease (ie, children, adults and women of childbearing age).

Resource utilization: Information on resource use associated with the diseases and for outbreak control came from two sources. In fall 1995, a panel of 16 physicians and health practitioners in Quebec were interviewed to collect their views on treatment protocols for each disease, the diseases' associated complications and for complications arising from the vaccine itself. This panel included physicians (general practitioners, pediatricians and obstetricians), nurses and other health care professionals. Data on control of outbreaks in Quebec were collected via interviews with two Quebec public health professionals.

Outbreak control was defined as a small-scale vaccination program limited to the number of cases in a small area or closed population. For example, if five children at the same school were to contract one of the diseases, all the other children at the school would be vaccinated with another dose of MMR vaccine. Resources considered focused on the organization and implementation of control measures for a typical outbreak of a limited number of cases in an urban school with 2000 children.

Cost structure: Costs were determined for the province of Quebec and extrapolated to the rest of Canada. Per diem rates were used for hospitalization and institutionalization (long term care facilities and special schools). The cost of physician fees and out-patient investigations and procedures were evaluated using the tariffs outlined by the Régie de l'assurance-maladie. Allied health consultations were assessed using an average hourly rate (salary and benefits). Medication (including dispensing fees) and medical equipment costs were determined from market prices. The cost of days missed from work was estimated using the average daily income in Canada (24).

Costs of the disease, complications related to the disease, complications from the vaccine, and outbreak control were incorporated in the model. Both first-year costs and follow-up costs were distinguished for each disease and its associated complications. Lifetime costs were evaluated for a 40-year period and included the first-year cost and 39 years of follow-up costs. First-year costs included diagnosis and acute care; follow-up cost involved maintenance treatment of a chronic condition. The administrative cost for the vaccine program was not included because it was assumed that the vaccine would be administered during a regular consultation at 18 months of age.

A break-even analysis was performed to discover when a $\mathrm{MOH}$ would recover its costs for implementing a routine second dose MMR vaccination program.

Sensitivity analyses: As recommended in the Canadian Guidelines for Economic Evaluations of Pharmaceuticals (25), costs were discounted at a rate of $5 \%$ to calculate benefit-cost ratios as well as the total cost per case avoided. To confirm the accuracy of initial estimates, the discount rate was then varied from zero (undiscounted) to $7 \%$. The sensitivity analysis was performed to confirm the consistency of the findings over an appropriate range. To test the sensitivity of the model to the probability of a complication, probabilities of the most expensive complications for each disease were varied by plus or minus $20 \%$.

\section{RESULTS}

For the predicted birth cohort of 400,000 assessed over the 20-year period of the model, it was estimated that a routine second dose of MMR vaccine would prevent 9200 cases of 
TABLE 4

Estimated lifetime costs per measles, mumps or rubella case with and without complications

\begin{tabular}{|c|c|c|}
\hline Disease & $\begin{array}{c}\text { Ministry of health } \\
\text { (cost/case - } \\
1995 \text { dollars) }\end{array}$ & $\begin{array}{c}\text { Society } \\
\text { (cost/case - } \\
1995 \text { dollars) }\end{array}$ \\
\hline \multicolumn{3}{|l|}{ Measles } \\
\hline Uncomplicated & 24 & 299 \\
\hline \multicolumn{3}{|l|}{ With complications } \\
\hline Otitis & 91 & 512 \\
\hline Pneumonia & 895 & 1,753 \\
\hline Encephalitis & $1,970,419$ & $1,971,587$ \\
\hline \multicolumn{3}{|l|}{ Mumps } \\
\hline Uncomplicated & 28 & 222 \\
\hline \multicolumn{3}{|l|}{ With complications } \\
\hline Encephalitis & 720 & 1,003 \\
\hline Orchitis & 71 & 354 \\
\hline Meningitis & 67 & 395 \\
\hline Deafness & 112,129 & 377,964 \\
\hline \multicolumn{3}{|l|}{ Rubella } \\
\hline Uncomplicated & 28 & 103 \\
\hline \multicolumn{3}{|l|}{ With complications } \\
\hline Thrombocytopenia & 137 & 212 \\
\hline Arthritis & 69 & 144 \\
\hline $\begin{array}{l}\text { Congenital rubella } \\
\text { syndrome* }\end{array}$ & 824,931 & $1,081,565$ \\
\hline
\end{tabular}

measles, 6120 cases of mumps and 1960 cases of rubella (Table 3). The second dose of MMR vaccine would also reduce the predicted number of complicated cases of each disease (Table 3).

The cost of treating cases of the three diseases without complications is relatively small (Table 4). From the MOH perspective the per patient costs for uncomplicated measles $(\$ 24)$, mumps $(\$ 28)$ or rubella $(\$ 28)$ reflect a single physician visit. The higher cost in the society perspective is due to the inclusion of indirect costs from work days lost by a caregiver. However, these illnesses can become expensive when problems occur (Table 4), the most costly complications being associated with measles encephalitis. The values shown reflect the overall lifetime cost of the complications which, from the societal perspective, include direct medical, direct nonmedical and indirect costs. However, these separate cost components had different impacts on the overall cost of each complication. To identify the role of each component, the cost of the three most expensive complications was broken down into direct medical, direct nonmedical and indirect costs, and the sources of each cost were identified (Table 5). In the case of direct costs, this breakdown reflected the way in which a patient with a particular complication was treated.

By far the largest direct medical cost was associated with the lifetime treatment of mumps or rubella deafness, which was 25 -fold higher than the direct medical cost resulting from CRS mental retardation. The major cost drivers in the long term care of deaf patients are investigations and medical
TABLE 5

Estimated lifetime costs from a societal perspective of the most expensive complications from measles, mumps and rubella

\begin{tabular}{|c|c|c|c|}
\hline & \multicolumn{3}{|c|}{ Total cost per patient } \\
\hline & $\begin{array}{l}\text { Encephalitis } \\
\qquad(1995 \\
{\text { dollars })^{*}}^{*}\end{array}$ & 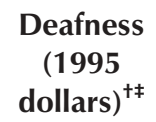 & $\begin{array}{l}\text { CRS-mental } \\
\text { retardation } \\
(1995 \text { dollars })^{\ddagger}\end{array}$ \\
\hline \multicolumn{4}{|l|}{ Direct costs } \\
\hline Consultations & 652 & 31 & 546 \\
\hline Hospitalization & 8,453 & 0 & 0 \\
\hline Investigations & 0 & 6,600 & 46 \\
\hline $\begin{array}{l}\text { Allied health } \\
\text { workers }\end{array}$ & 0 & 109 & 93 \\
\hline Medication & 0 & 0 & 0 \\
\hline $\begin{array}{l}\text { Medical } \\
\text { equipment }\end{array}$ & 0 & 10,386 & 0 \\
\hline Total & 9,105 & 17,126 & 685 \\
\hline \multicolumn{4}{|l|}{ Indirect costs } \\
\hline \multicolumn{4}{|c|}{ Days missed from work } \\
\hline $\begin{array}{l}\text { Caregivers } \\
\text { and patients }\end{array}$ & 893 & 88,213 & 4,196 \\
\hline $\begin{array}{l}\text { Long term } \\
\text { disability }\end{array}$ & 0 & 21,428 & 21,428 \\
\hline Total & 893 & 109,641 & 25,624 \\
\hline \multicolumn{4}{|c|}{ Direct nonmedical costs } \\
\hline Special schools & 0 & 156,000 & 0 \\
\hline $\begin{array}{l}\text { Institutionaliza- } \\
\text { tion }\end{array}$ & $1,961,291$ & 94,789 & 904,278 \\
\hline Rehabilitation & 0 & 186 & 887,125 \\
\hline Total & $1,961,291$ & 250,975 & $1,791,403$ \\
\hline
\end{tabular}

equipment. Mumps or rubella deafness also had the largest indirect cost impact, an impact that was 123-fold and fourfold higher than those associated with encephalitis and CRS mental retardation, respectively (Table 5). However, because measles-related encephalitis and rubella-related CRS mental retardation are associated with extensive institutionalization and, in the latter case, rehabilitation, the direct nonmedical costs for these diseases were substantial, and this component was a major determining factor in their overall lifetime costs. For example, the direct nonmedical cost of institutionalization relating to measles encephalitis contributed $99.4 \%$ of the overall lifetime cost of the disease.

Benefit-cost ratios for the program to revaccinate all Canadian children routinely at age 18 months are presented in Table 6 . These ratios were calculated by dividing the cost saved from disease averted with a second dose program less the cost saved with the single dose program by the total cost of implementing a program for a second dose of MMR at 18 months minus the cost of the program for a single dose. Under the MOH perspective, discounted benefit-cost ratios demonstrated that each dollar invested in a routine second vaccination with 
TABLE 6

Benefit-cost ratios and sensitivity analysis

\begin{tabular}{lcc}
\hline \multicolumn{2}{c}{ Benefit-cost ratios* } \\
Discount rate (\%) & Ministry of health & Society \\
\hline $\begin{array}{c}\text { Primary analysis } \\
5\end{array}$ & 6.34 & 3.25 \\
Secondary analysis & & \\
0 & 8.99 & 4.61 \\
3 & 7.08 & 3.64 \\
7 & 5.84 & 3.00 \\
\hline
\end{tabular}

*Benefit-cost ratios were calculated by dividing the cost saved from disease averted with a second dose program less the cost averted with the single dose program by the total cost of implementing a program for a second dose of measles, mumps and rubella vaccine at 18 months minus the cost of the program for a single dose

MMR vaccine resulted in $\$ 6.34$ saved because significant numbers of cases of these illnesses were averted. Break-even analysis, performed to discover when a MOH would recover its costs for implementing a routine second dose MMR vaccination program, demonstrated that for the large population considered (400,000 children per year) at any given point benefits would outweigh costs, resulting in an immediate cost recovery.

Similarly, results under the society perspective indicated that $\$ 3.25$ in illness-related costs would be avoided for each dollar invested. The unexpected difference between the benefit-cost ratios for the two perspectives was attributed to additional indirect costs in the societal perspective. For instance, parents must take time off work to care for a child who has a reaction to the vaccine (eg, anaphylaxis or fever). While this loss of income is an additional cost to society, it was not accounted for under the $\mathrm{MOH}$ perspective.

To test the robustness of the data, two types of sensitivity analysis were carried out. For the primary analysis the benefit-cost ratio was determined using a discount rate of $5 \%$ per year. When the discount rate was varied from zero to $7 \%$, the benefit-cost ratios from both perspectives decreased (Table 6), demonstrating that the ratios were sensitive to the discount rate used in the calculations. Because the overall cost of each disease may be highly dependent on the probability of complications, the probabilities of the most expensive complications for each disease were varied in a second sensitivity analysis (Table 7). This variation produced no major changes in the benefit-cost ratios from either perspective, suggesting that the ratios were relatively insensitive to large changes in the probability of major complications. The largest change occurred when the probability of measles encephalitis was varied by plus or minus $20 \%$. Under these circumstances the corresponding benefit-cost ratios varied by $11 \%$ and $9 \%$ from the $\mathrm{MOH}$ and societal perspectives, respectively.

\section{DISCUSSION}

Despite high vaccination rates in Canada, certain individuals remain susceptible to MMR because of primary or secondary vaccine failure and because vaccination coverage has not
TABLE 7

Benefit-cost ratios for sensitivity analysis of the probabilities of the most expensive complications of measles, mumps and rubella

\begin{tabular}{lcccc}
\hline & \multicolumn{4}{c}{ Benefit-cost ratios } \\
& \multicolumn{1}{c}{ Ministry of health } & \multicolumn{2}{c}{ Society } \\
Complications & $\mathbf{- 2 0 \%}$ & $\mathbf{+ 2 0 \%}$ & $\mathbf{- 2 0 \%}$ & $\mathbf{+ 2 0 \%}$ \\
\hline $\begin{array}{l}\text { Measles - } \\
\text { encephalitis } \\
\begin{array}{c}\text { Mumps - } \\
\text { deafness }\end{array}\end{array}$ & 5.66 & 7.01 & 2.97 & 3.53 \\
$\begin{array}{l}\text { Rubella - } \\
\text { deafness } \\
\begin{array}{l}\text { Rubella - } \\
\text { mental retardation }\end{array}\end{array}$ & 6.34 & 6.34 & 3.25 & 3.25 \\
\hline
\end{tabular}

reached $100 \%$ of the preschool population. Mathematical models predict that nationwide outbreaks of measles in excess of 20,000 cases are possible in the near future (5). Outbreaks of mumps and rubella are also a possibility in highly vaccinated populations $(10,26,27)$. For example, Cheek et al (28), studying a mumps outbreak in highly vaccinated schoolchildren, concluded that vaccination failure plays a significant role in contemporary mumps outbreaks. From a clinical perspective, most children have been shown to retain protective antibodies when vaccinated with a second dose of MMR vaccine. From an economic perspective, a routine second dose of MMR vaccine is a medical intervention that actually produces cost savings.

From both the $\mathrm{MOH}$ and society perspectives, the potential savings are enormous if outbreaks can be averted. The routine second dose strategy provides clear savings to the Canadian health care system. For each dollar spent on this medical intervention, projected savings were $\$ 6.34$ because these diseases and their complications will not occur. Break-even analysis was performed to discover when a $\mathrm{MOH}$ would recover its costs for implementing a routine second dose program. Results showed that there was an immediate cost recovery when a large cohort of 400,000 children per year was vaccinated.

Apart from the economic benefits of a second dose of MMR vaccine, children and their families benefit because they do not experience the suffering and discomfort of the diseases and their associated complications. These intangible costs were not assessed in the present study, which was restricted to the measurement of tangible costs, but clearly they may have a substantial impact on the overall societal burden of the three diseases.

The absence of primary clinical and economic data presented potential limitations for this study. Epidemiological data were gathered from published and unpublished sources in the United States and Canada, and these data were the source of the probabilities of complications arising from each disease. Because expensive complications may have a significant impact on the overall cost of each disease, the probabilities governing the occurrence of these complications were varied in a sensitivity analysis. The benefit-cost ratios determined were relatively insensitive to a $20 \%$ variation in the probability 
of an expensive complication occurring, suggesting that the calculated ratios were robust and not highly dependent on the cost of rare, but expensive, complications. This observation also indicated that the ratios determined were not dependent on a single expensive complication but rather reflected the overall economic impact of all three diseases.

Resource utilization estimates were based on information from the literature and on interviews with experts. In general, physicians and health practitioners tend to underestimate resource consumption; as a result, the real costs and benefitcost ratios were perhaps underestimated. However, in the interest of maintaining a conservative focus, this was considered acceptable. As well, the number of health care professionals interviewed was relatively small (16); thus the sample may not have been completely representative. Nonetheless, by contacting people from different disciplines and from community health centres, any imbalance that may have resulted from differences in patterns of practice should have been corrected for.

It was not possible to capture the cost of abortions for women who contracted rubella during their pregnancy in these calculations; probabilities for the number of women who became pregnant and the number of abortions attributed to congenital rubella syndrome did not exist. As a result, resource utilization again may have been underestimated, and the benefits of the second dose program might be greater than the results of this study demonstrate.

Two further factors may have contributed some distortion to the study. First, costs were estimated for Quebec and then extrapolated to Canada as a whole; and second, the model only covers a 20 -year period.

Results of this evaluation of MMR vaccine were compared with previously published economic evaluations of different vaccines. White et al (3) compared the benefits (ie, clinical outcomes) for children who received one injection of MMR vaccine with the benefits for those who received no vaccination at all. The higher benefit-cost ratio for the society perspective reported by White et al (14.4) compared with this study (3.25) was attributed to the fact that the vaccine was being administered to children for the first time. A benefit-cost analysis performed in 1985 suggested that a varicella vaccine that provided lifelong immunity would save $\$ 7$ in costs to society for every dollar invested in vaccination (29). In another study, the benefits of receiving one injection of a mumps vaccine versus receiving no vaccine at all were compared, and a cost:benefit ratio of 7.4 was reported (2). Schoenbaum et al (30) calculated a benefit-cost ratio associated with receiving two injections of a vaccination against rubella of 23 . While the results of these studies are not directly comparable, the benefit-cost ratios generated by the model in the current study may be considered at least as positive as others reported above.

\section{CONCLUSIONS}

The model developed in this study was used to project the costs associated with a routine second dose of MMR vaccine, administered at approximately 18 months of age. The model predicted benefit-cost ratios that are comparable with other published studies. In this study, routine second dose immuni- zation with MMR vaccine provided significant cost savings compared with a single injection at 12 months of age.

The results of this study also indicated that the routine second dose immunization with MMR vaccine would prevent thousands of cases of MMR. As a direct consequence, associated complications and their costs would also be avoided. Both ministries of health and society can anticipate important monetary savings, and much needless suffering can be prevented. Results of this study are in line with the recent recommendations of the National Advisory Council on Immunization that a second dose of MMR vaccine be offered routinely, at least one month after the first dose, to raise protection rates against MMR (5).

ACKNOWLEDGEMENTS: This study was sponsored by Merck Frosst Canada Inc. We thank Dr Gaston DeSerres from the Centre de Santé Publique du Québec, Québec, Québec for providing needed information.

\section{REFERENCES}

1. Carter H, Campbell H. Rational use of measles, mumps and rubella (MMR) vaccine. Drugs 1993;45:677-83.

2. Koplan JP, White CC. An update on the benefits and costs of measles and rubella vaccination. In: Gruenberg EM, Lewis C, Goldston S, eds. Immunizing Against Mental Disorders: Progress in the Conquest of Measles and Rubella. New York: Oxford University Press, 1985:77-127.

3. White CC, Koplan JP, Orenstein WA. Benefits, risks and costs of immunization for measles, mumps and rubella. Am J Public Health 1985;75:739-44.

4. Rapport du groupe de travail sur la rougeole du comité d'ímmunisation du Québec. Utilisation d'une seconde dose de vaccin contre la rougeole et intervention lors d'éclosions. Québec: Comité d'immunization du Québec, 1994.

5. National Advisory Committee on Immunization. Supplementary Statement on Measles Elimination in Canada. Can Commun Dis Rep 1996;22:9-15.

6. Markowitz LE, Albrecht P, Orenstein WA, et al. Persistence of measles antibody after revaccination. J Infect Dis 1992;166:205-8.

7. Wood DL, Brunell PA. Measles control in the United States: Problems of the past and challenges for the future. Clin Microbiol Rev 1995;8:260-7.

8. Centers for Disease Control. Measles prevention: recommendations of the Immunization Practice Advisory Committee (ACIP). MMWR 1989;38:1-17.

9. Gouvernement du Québec, Ministère de la santé et des services sociaux, Services des communications. Communiqué: Le Québec prend des mesures pour prévenir l'épidémie de rougeole appréhendée en1996. Decembre 1995.

10. Bussières N. Rapport "Activité Ourlienne 1988-1989". Département de Santé Communautaire du Centre Hospitalier Régional du Grand-Portage. Internal report, 1990.

11. Peltola H, Heinonen OP, Valle M, et al. The elimination of indigenous measles, mumps, and rubella from Finland by a 12-year, two-dose vaccination program. N Engl J Med 1994;331:1397-402.

12. Tulchinsky TH, Ginsberg GM, Abed Y, et al. Measles control in developing and developed countries: The case for a two-dose policy. Bull World Health Organ 1993;71:93-103.

13. National goals and objectives for the control of vaccine-preventable diseases of infants and children. Can Commun Dis Rep 1995;21:49-56.

14. Measles update: Ontario and Quebec announce a routine two-dose measles vaccine program and a supplementary catch-up program. Health Canada, November/December $1995 ; 3(4)$.

15. Waters JR. To: All Medical Officers of Health, Re: Measles 
Immunization - Two Dose Programs. Alberta Health memo dated January 5, 1996.

16. Reynolds D. CJCH/Halifax, Mediascan \#6-353839 (22). March 22, 1996.

17. Measles update: Update on Implementation of Routine Twodose Measles Vaccination Schedule and Supplementary Catchup Programs. Health Canada. November/December 1996;4(4).

18. Statistics Canada. Births [catalogue 84-210]. Ottawa: Statistics Canada, 1991:4, Table 1B.

19. De Serres G. Impact d'une seconde dose de vaccin contre la rougeole, la rubéole et les oreillons dans le calendrier régulier de vaccination et lors de campagnes de rattrapage. Data presented to Comite d'immunization du Québec, October, 1995.

20. Expected number of cases of measles, mumps, rubella that would occur with a single dose program of MMR. Data presented to National advisory Committee on Immunization, August 30 , 1995.

21. Consensus Conference on Measles. Can Commun Dis Rep 1993;19:72-9.

22. Behrman RE, Kliegman RM, Nelson WE, Vaughan VC, eds. Nelson Textbook of Pediatrics, 14th edn. Philadelphia: WB Saunders Co, 1992.
23. Preblud SR, Katz SL. Chapter 9. In: Plotkin SA, Mortimer EA, eds. Vaccines. Measles vaccine. Philadelphia: WB Saunders Co, 1988:182-222.

24. Statistics Canada. Income distributions by size in Canada, 1992. Ottawa: Statistics Canada, 1993:19, Table 1

25. Canadian Coordinating Office for Health Technology Assessment. Guidelines for Economic Evaluations of Pharmaceuticals: Canada, 1st edn. Ottawa: Canadian Coordinating Office for Health Technology Assessment, 1994.

26. Mumps - United States, 1985-1988. MMWR 1989;38:101-5.

27. Increase in rubella and congenital rubella syndrome - United States, 1988-1990. MMWR 1991;40:93-9.

28. Cheek JE, Baron R, Atlas H, et al. Mumps outbreak in a highly vaccinated school population. Evidence for largescale vaccination failure. Arch Pediatr Adolesc Med 1995;149:774-8.

29. Preblud SR, Orenstein WA, Koplan JP, et al. A benefit-cost analysis of a childhood varicella vaccination programme. Postgrad Med J 1985;61(Suppl 4):17-22.

30. Schoenbaum SC, Hyde JN, Bartoshesky L, Crampton K. Benefit-cost analysis of rubella vaccination policy. $\mathrm{N}$ Engl J Med 1976;294:306-10. 


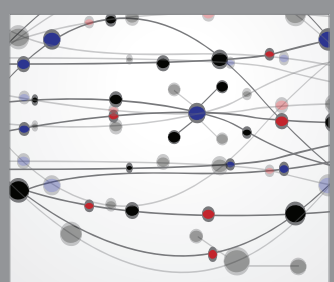

The Scientific World Journal
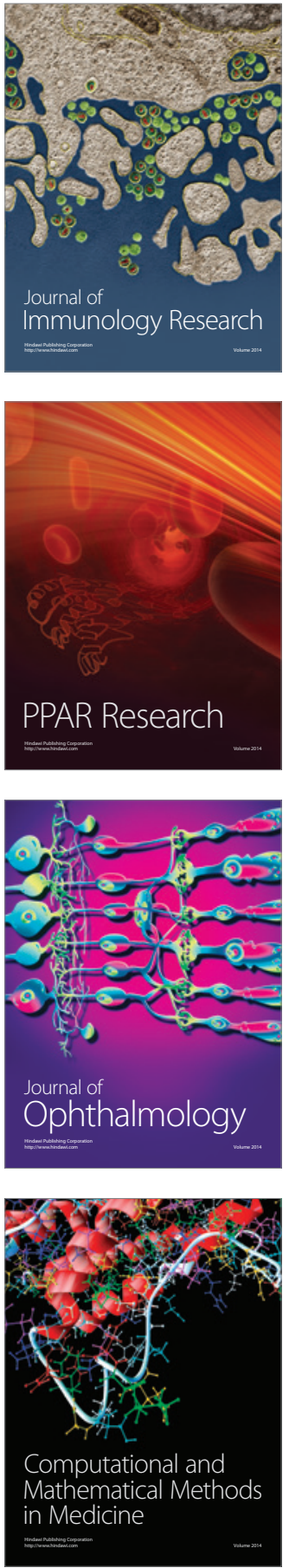

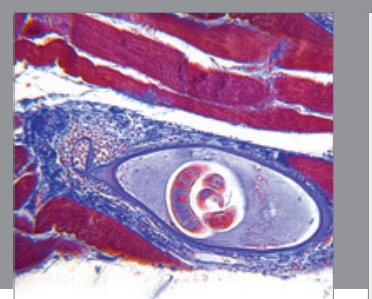

Gastroenterology Research and Practice

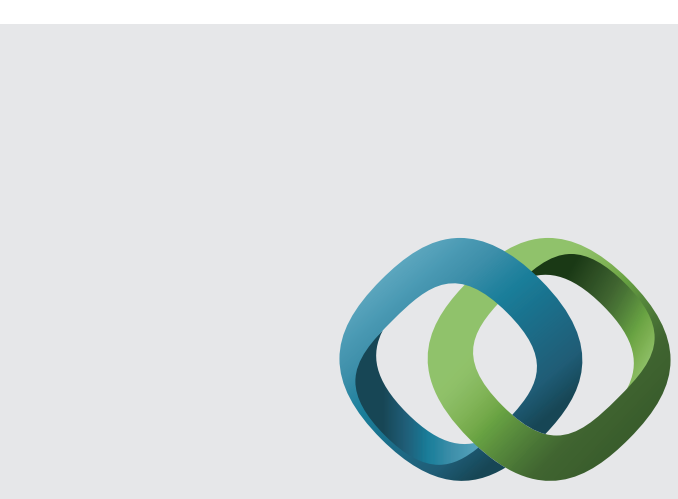

\section{Hindawi}

Submit your manuscripts at

http://www.hindawi.com
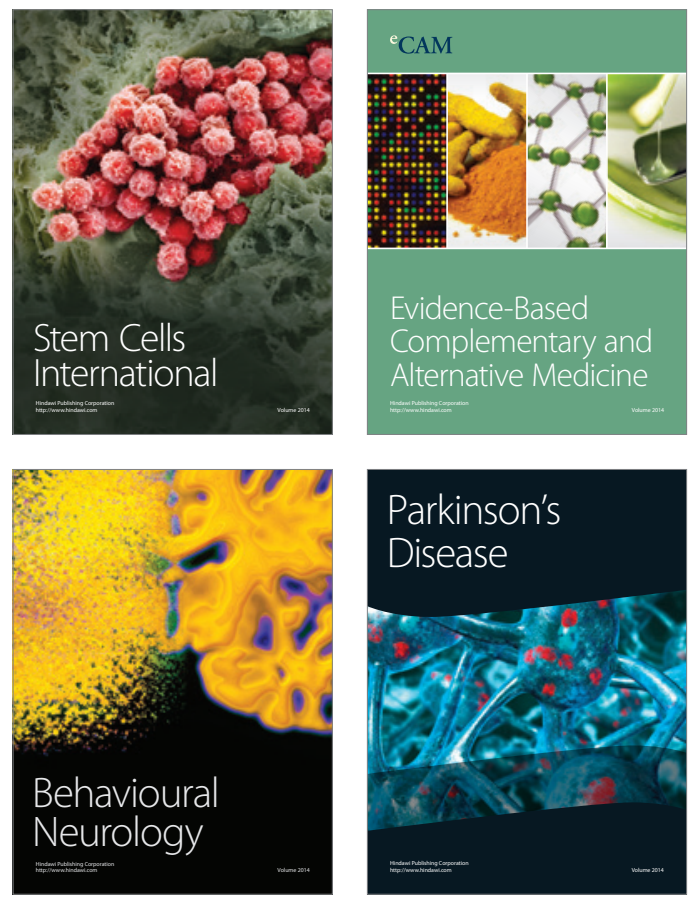
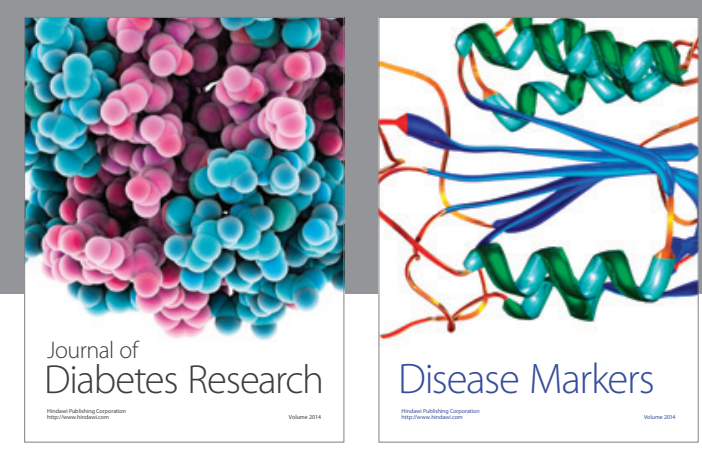

Disease Markers
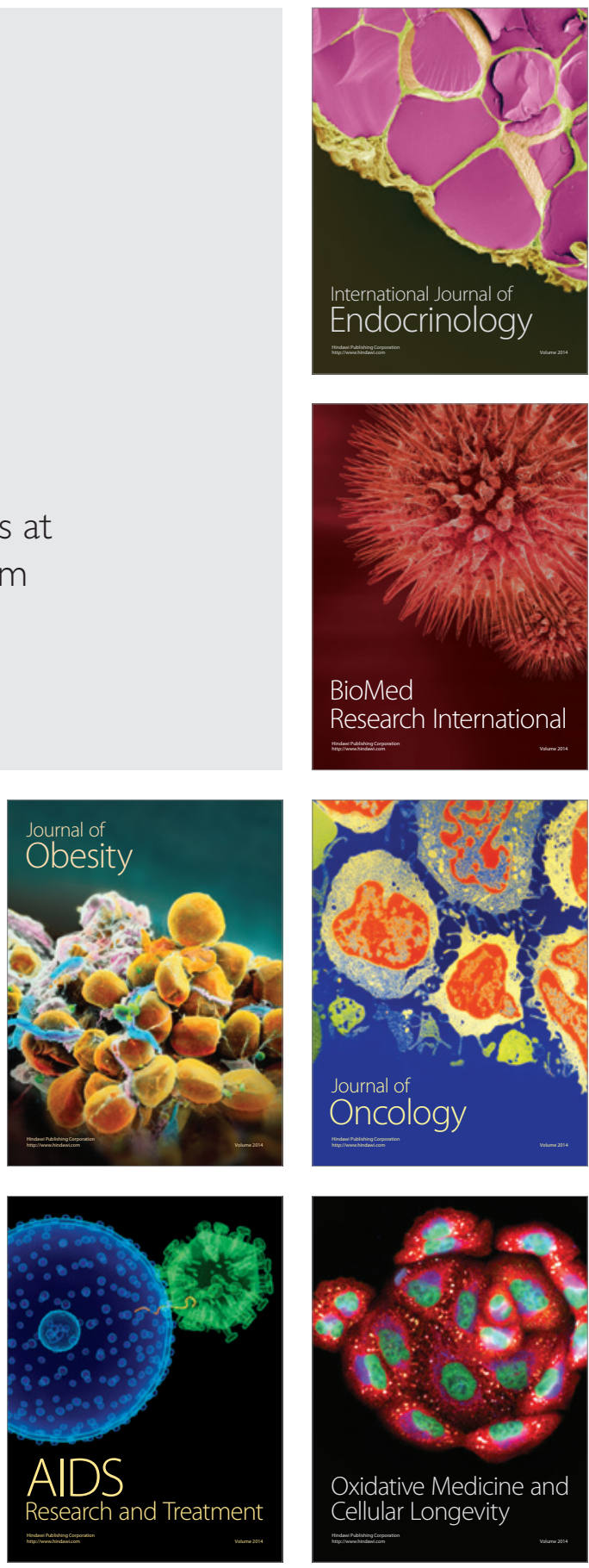